\title{
Dịch vụ và người mua dịch vụ môi trường rừng ngập mặn tiềm năng tại Việt Nam - kết quả từ nghiên cứu tại Hải Phòng
}

\author{
Phạm Thu Thủy ${ }^{\mathrm{a}}$, Hoàng Tuấn Long ${ }^{\mathrm{a}}$, Đào Thị Linh Chi ${ }^{\mathrm{a}}$, Hà Châu Ngôa ${ }^{\mathrm{a}}$, Hoàng Minh Hiếu ${ }^{\mathrm{a}}$, \\ Hoàng Thị Uyên ${ }^{\mathrm{a}}$, Hoàng Thị Thu Thủy ${ }^{\mathrm{a}}$, Nông Nguyễn Khánh Ngọca ${ }^{\mathrm{a}}$, Nguyễn Đình Tiến ${ }^{\mathrm{a}}$, \\ Trương Văn Vinh ${ }^{b}$, Nguyễn Thành $\mathrm{Nho}^{\mathrm{b}}$
}

\section{Thông điệp chính}

- Cơ chế chi trả dịch vụ môi trường rừng (PFES) đối với rừng ngập mặn tại Việt Nam có thể áp dụng với 8 loại dịch vụ môi trường chính: 1) Dịch vụ hấp thụ, lưu trữ, bể chứa các-bon; 2) Dịch vụ giảm bồi lắng và lượng bùn thải; 3) Dịch vụ chống xói lở bờ biển; 4) Dịch vụ chắn sóng; 5) Dịch vụ cung ứng nước sạch, lọc kim loại nặng và chất ô nhiễm; 6) Dịch vụ cung ứng bãi đẻ; 7) Dịch vụ vẻ đẹp cảnh quan; 8) Dịch vụ cung cấp nguyên liệu thực phẩm.

- Có 20 nhóm người mua dịch vụ môi trường rừng ngập mặn tiềm năng trên địa bàn Hải Phòng bao gồm: Công ty doanh nghiệp nạo vét, công ty năng lượng, ngành giải trí, ngành ngân hàng, ngành vận tải hàng không, cảng cá, cảng biển, khu kinh tế ven biển, công ty khai thác cát, ngành khai thác khoáng sản và luyện kim, ngành vận tải, ngành nhiệt điện, các nhóm quản lí đê điều, công ty du lịch, cộng đồng dân cư, công nghiệp đóng tàu, công ty sản xuất mặt hàng nông, lâm, thủy hải sản, công ty xăng dầu và công ty nước sạch. Trong khi một số nhóm người mua đã thể hiện cam kết cao cho việc tiến hành chi trả (vd: Ngân hàng, Năng lượng, Công ty sản xuất các sản phẩm nông, lâm thủy hải sản), nhưng cần có thêm nhiều nghiên cứu trong tương lai để tìm hiểu mức sẵn lòng chi trả của các bên còn lại trong việc tham gia PFES.

- Trong bối cảnh của Hải Phòng, hai dịch vụ môi trường là dịch vụ nước sạch và lọc kim loại nặng cùng với dịch vụ chi trả các-bon nêu trên có số lượng người mua tiềm năng lớn nhất.

- Để xây dựng cơ chế chi trả cho các dịch vụ môi trường rừng ngặp mặn tiềm năng kể trên, cần phải trả lời được 4 câu hỏi chính: (1) Chi trả cho dịch vụ nào? (2) Ai là người chi trả? (3) Mức chi trả là bao nhiêu? và (4) Cơ chế thu chi như thế nào? Việc trả lời 4 câu hỏi trên đòi hỏi phải có các nghiên cứu bài bản trong một thời gian đủ dài. Đặc biệt, minh chứng cho mối quan hệ giữa các bên đối với dịch vụ môi trường rừng sử dụng. Dựa trên kết quả nghiên cứu tiền khả thi năm 20182019, tóm lược chính sách này trả lời 2 câu hỏi đầu. Hai câu hỏi cuối sẽ được trả lời tại một tóm lược chính sách khác sau khi nghiên cứu hoàn thành vào cuối năm 2020.

\section{Bối cảnh}

Tầm quan trọng về sinh thái, môi trường và kinh tế của rừng ngập mặn đã được công nhận rộng rãi trên toàn thế giới và được giới khoa học trong và ngoài nước chứng minh với các số liệu ở các quy mô và vùng sinh thái khác nhau. Trong báo cáo gần đây, Ủy ban Thích ứng Khí hậu Toàn cầu (The Global Adaptation Commission) nhấn mạnh rằng lợi ích từ việc bảo

a CIFOR

b NLU-HCMC vệ và tái sinh rừng ngập mặn (ví dụ từ thủy sản, lâm nghiệp, cảnh quan sinh thái và giảm thiểu rủi ro) có thể gấp 10 lần so với chi phí bỏ ra. Hiện nay, do diện tích rừng ngập mặn đang suy giảm nhanh chóng, việc bảo vệ và phát triển rừng ngập mặn đã trở thành một trong những ưu tiên hàng đầu của Việt Nam. Chính sách chi trả dịch vụ môi trường rừng tại Việt Nam (PFES) đã có quy định chi trả cho dịch vụ môi trường rừng ngập mặn thông qua dịch vụ nuôi trồng thủy sản và cung ứng bãi đẻ. Tuy nhiên, việc thực hiện cơ chế chi trả cho dịch vụ này còn gặp nhiều khó khăn và chưa tính tới các tiềm năng to lớn của dịch vụ môi trường khác mà rừng ngập mặn có thể đem lại. Dựa trên nghiên cứu tại Hải Phòng, báo 
cáo này đánh giá tiềm năng mở rộng cơ chế dịch vụ môi trường rừng ngập mặn với nhiều dịch vụ và người mua dịch vụ mới. Báo cáo này là sản phẩm của dự án Giảm thiểu và thích ứng đất ngập nước bền vững (SWAMP) do USAID và dự án Nghiên cứu so sánh REDD+ toàn cầu (GCS-REDD+) do NORAD tài trợ. Báo cáo hi vọng sẽ cung cấp các thông tin đầu vào cho việc mở rộng nguồn thu PFES sau này.

\section{Phương pháp}

Nghiên cứu được tiến hành ở Hải Phòng trong năm 20182019. Hải Phòng được chọn làm điểm nghiên cứu bởi nhiều nguyên nhân. Thứ nhất, diện tích rừng ngập mặn tại Hải Phòng đang giảm đi nhanh chóng và chính quyền Thành phố đã có những cam kết mạnh mẽ trong việc bảo vệ và mở rộng diện tích rừng ngập mặn. Thứ hai, Hải Phòng là cảng biển lớn nhất tại miền Bắc Việt Nam cũng như có tiềm năng phát triển kinh tế biển vượt trội so với các tỉnh lân cận. Tại Hải Phòng có đầy đủ các nhóm người sử dụng dịch vụ môi trường rừng cần khảo sát như du lịch sinh thái, sản xuất nuôi trồng thủy hải sản, cảng cá và cảng biển, vận chuyển và khai thác khoáng sản. Thứ ba, tại Hải Phòng đã có nhiều nhóm người mua dịch vụ môi trường rừng đã trả tiền để bảo vệ rừng ngập mặn một cách tự nguyện như công ty Năng lượng Stadtwerke Münster của Đức, ngân hàng Standard Charter và một số doanh nghiệp trên địa bàn. Điều này minh chứng cho tiềm năng dịch vụ mà rừng ngập mặn đem lại cũng như mối quan tâm của người mua đối với dịch vụ môi trường này. Nghiên cứu cũng đi đúng định hướng phát triển kinh tế bền vững mà Hải Phòng đã đề ra, đặc biệt với ưu tiên tăng bảo tôn các giá trị sinh thái. Điều này cho thấy nhiều thuận lợi về mặt cam kết chính trị cũng như hành lang pháp lí cho việc hỗ trợ hình thành cơ chế chi trả cho dịch vụ môi trường rừng ngập mặn tại Hải Phòng.
Để xác định dịch vụ mới và người chi trả tiềm năng cho các dịch vụ môi trường rừng do rừng ngập mặn đem lại, nhóm nghiên cứu đã sử dụng nhiều phương pháp kết hợp.

Nghiên cứu tài liệu thứ cấp. Các tài liệu nghiên cứu về vai trò và tiềm năng của rừng ngập mặn, các dịch vụ môi trường rừng ngập mặn, các báo cáo của cơ quan nhà nước, các doanh nghiệp, các tổ chức dân sự xã hội, các bài học kinh nghiệm trong xây dựng cơ chế chi trả dịch vụ môi trường rừng trong và ngoài nước được rà soát và phân tích kĩ lưỡng.

Phỏng vấn sâu. 50 cuộc phỏng vấn đã được thực hiện với các bên có liên quan với mục đích tìm hiểu quan điểm của các bên về:

- Vai trò, tầm quan trọng và đóng góp của rừng ngập mặn đối với từng ngành nghề và các bên có liên quan;

- Xác định người mua của từng dịch vụ môi trường rừng mà hiện nay rừng ngập mặn đang cung cấp ở Hải Phòng;

- Mức sẵn lòng chi trả của các bên để bảo vệ và phát triển rừng ngập mặn;

- Cơ hội và thách thức trong việc bảo vệ và phát triển rừng ngập mặn;

- Cơ hội và thách thức trong việc thực hiện chi trả dịch vụ môi trường rừng ngập mặn.

\section{Diễn biến rừng ngập mặn tại Hải Phòng và giá trị dịch vụ môi trường rừng ngập mặn}

Diện tích rừng ngập mặn tại Hải Phòng mặc dù có xu hướng tăng dần từ năm 2007-2015 nhưng có xu hướng giảm rõ rệt trong khoảng 3 năm trở lại đây, đặc biệt, diện

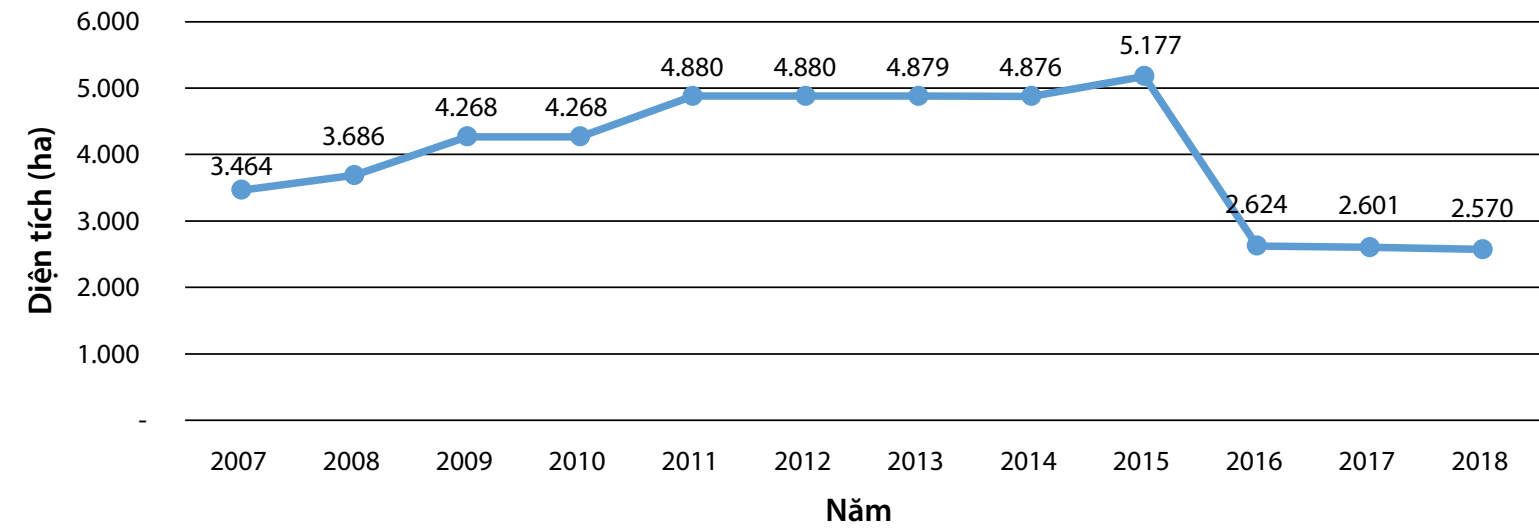

Hình 1. Diện tích rừng ngập mặn tại Hải Phòng qua các năm

Nguồn: Nhóm tác giả tổng hợp từ số liệu của TCLN - Bộ NN\&PTN 


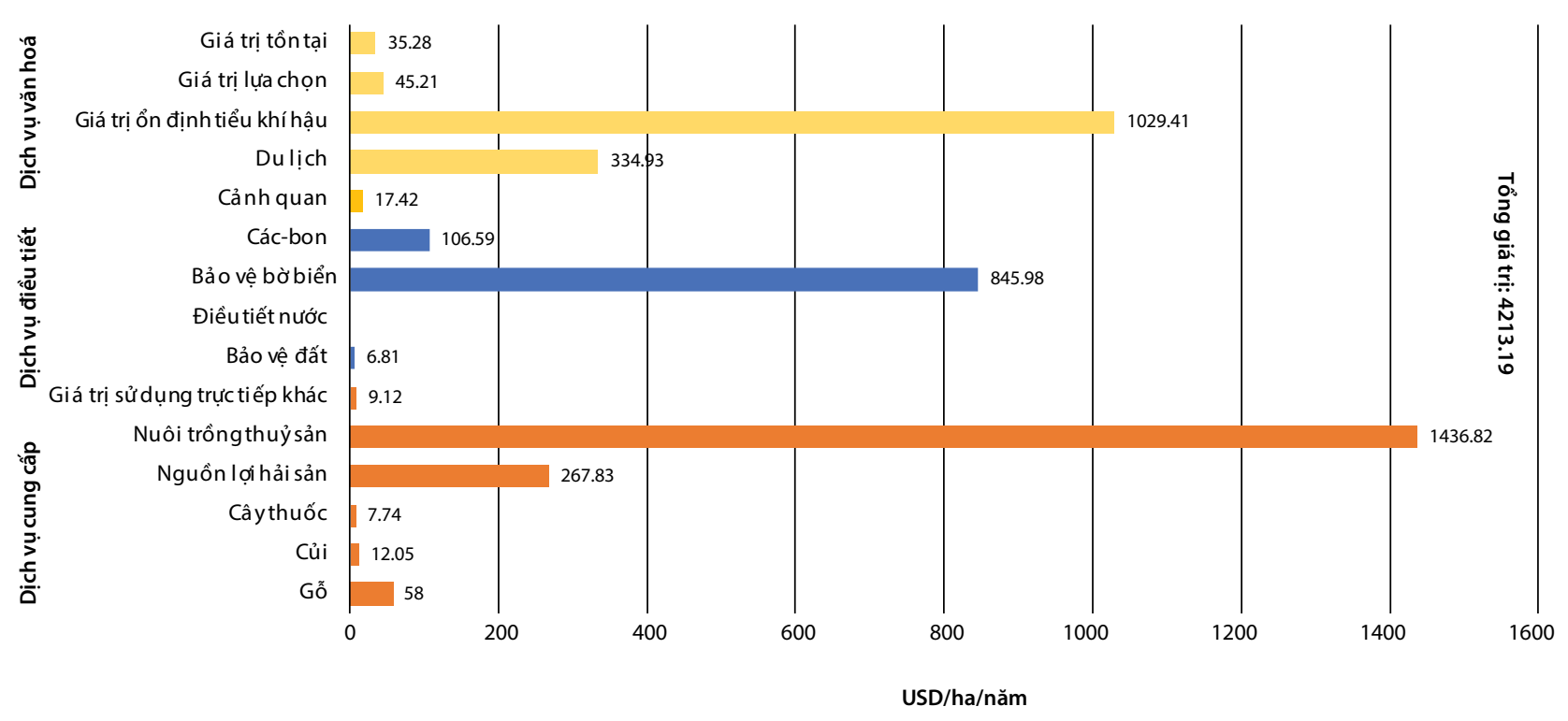

Hình 2. Giá trị trung bình của các dịch vụ môi trường rừng ngập mặn đem lại tại Việt Nam (Phạm và cộng sự, 2019)

tích rừng ngập mặn giảm đáng kể từ 5.177ha (2015) xuống còn 2.624ha (2016). Nếu không có những chính sách phù hợp, diện tích rừng ngập mặn tại Hải Phòng có thể bị biến mất gây ảnh hưởng đến đời sống sinh hoạt và sản xuất của người dân địa phương.

Phạm và cộng sự (2019) cũng đã tổng hợp nhiều nghiên cứu về định giá dịch vụ môi trường rừng ngập mặn tại các khu vực của Việt Nam từ giai đoạn 1990- 2019 và chỉ ra giá trị trung bình của các dịch vụ môi trường mà rừng ngập mặn trên cả nước rất cao và có thể lên tới 1436,82USD/ ha cho một dịch vụ riêng lẻ (Hình 2). Theo nhiều chuyên gia được phỏng vấn, giá trị dịch vụ môi trường rừng ở Hải Phòng cũng tối thiểu nằm trong số lượng định giá này và do vậy rất cần được bảo vệ và đầu tư xứng đáng.

\section{Các dịch vụ và người sử dụng dịch vụ mổi trường rừng ngập mặn tiềm năng tại Hải Phòng}

Kết quả từ nghiên cứu tiền khả thi tại Hải Phòng cho thấy, cơ chế chi trả dịch vụ môi trường rừng ngập mặn có thể được áp dụng với 8 loại dịch vụ môi trường rừng tiềm năng (Hình 3).

Bảng 1 tóm tắt dịch vụ môi trường rừng mà rừng ngập mặn có thể đem lại

Với mỗi loại dịch vụ khác nhau có các nhóm người mua tiềm năng khác nhau nhưng có thể thấy dịch vụ hấp thụ các

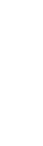

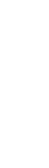

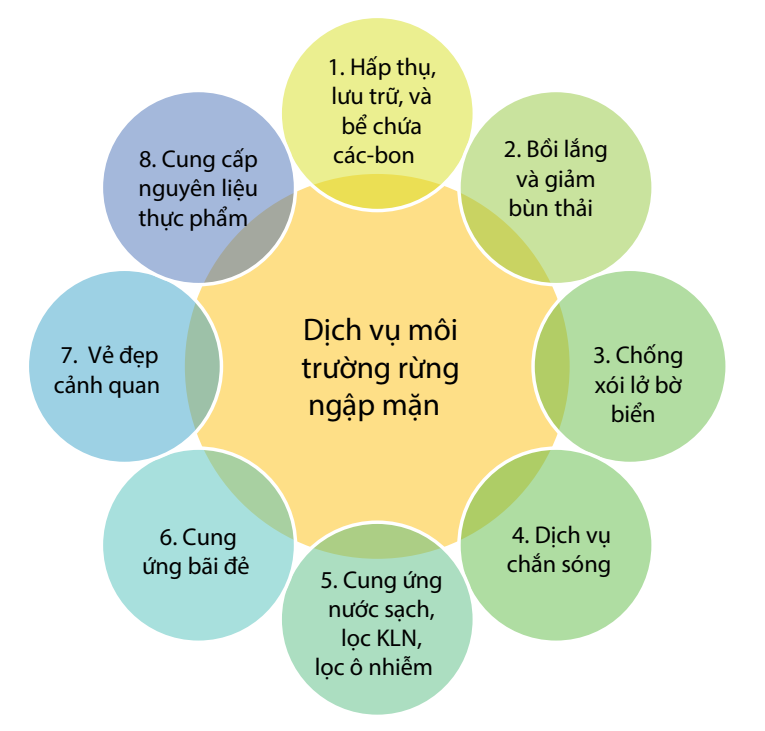

Hình 3. Các loại hình dịch vụ môi trường rừng ngập mặn có thể cung cấp và có thể xây dựng cơ chế PFES tại Việt Nam (Nguồn: Nhóm tác giả 2020)

bon và dịch vụ cung cấp nước sạch, lọc kim loại và giảm bồi lắng hiện đang có nhiều người sử dụng dịch vụ tiềm năng nhất (Hình 4). Hiện nay có trên 20 nhóm ngành nghề và người sử dụng dịch vụ môi trường rừng tại Hải Phòng và có thể là người mua tiềm năng trong cơ chế PFES. Hình 5 cũng cho thấy các nhóm người mua này phân bố ở khắp địa bàn Hải Phòng. 
Bảng 1. Dịch vụ môi trường rừng mà rừng ngập mặn có thể cung cấp

\begin{tabular}{|c|c|}
\hline Dịch vụ & Tóm tắt luận giải vai trò của rừng ngập mặn \\
\hline $\begin{array}{l}\text { 1. Hấp thụ, lưu trũ, bể } \\
\text { chứa các-bon }\end{array}$ & $\begin{array}{l}\text { - Rừng ngập mặn đóng vai trò đặc biệt quan trọng trong chu trình các-bon toàn cầu } \\
\text { - Với dòng đời dài và khả năng lưu giữ các-bon lâu bền, lượng các-bon RNM lưu trữ có thể cao } \\
\text { hơn từ 3-4 lần so với rừng nhiệt đới trên cạn (Alongi 2012).1 héc-ta rừng ngập mặn bị mất } \\
\text { tương đương với 3-5 héc-ta rừng nhiệt đới trên cạn bị mất (Sasmito và cộng sự 2019). Nhiều } \\
\text { nghiên cứu toàn cầu khác được tiến hành bởi CIFOR cũng cho thấy rừng ngập mặn là một } \\
\text { trong những kiểu rừng có trữ lượng các-bon cao nhất tại vùng nhiệt đới, chứa bình quân } 1.023 \\
\text { Mg các-bon trên mỗi héc-ta (Donato và cộng sự 2011). } \\
\text { - Việc phá rừng ngập mặn sẽ phát thải } 0,2-0,12 \text { Pg các-bon mỗi năm - chiếm khoảng } 10 \% \text { lượng } \\
\text { phát thải do phá rừng toàn cầu dù diện tích rừng ngập mặn chỉ chiếm } 0,7 \% \text { tổng diện tích } \\
\text { rừng nhiệt đới (Donato và cộng sự 2011). }\end{array}$ \\
\hline $\begin{array}{l}\text { 2. Giảm bồi lắng và } \\
\text { lượng bùn thải }\end{array}$ & 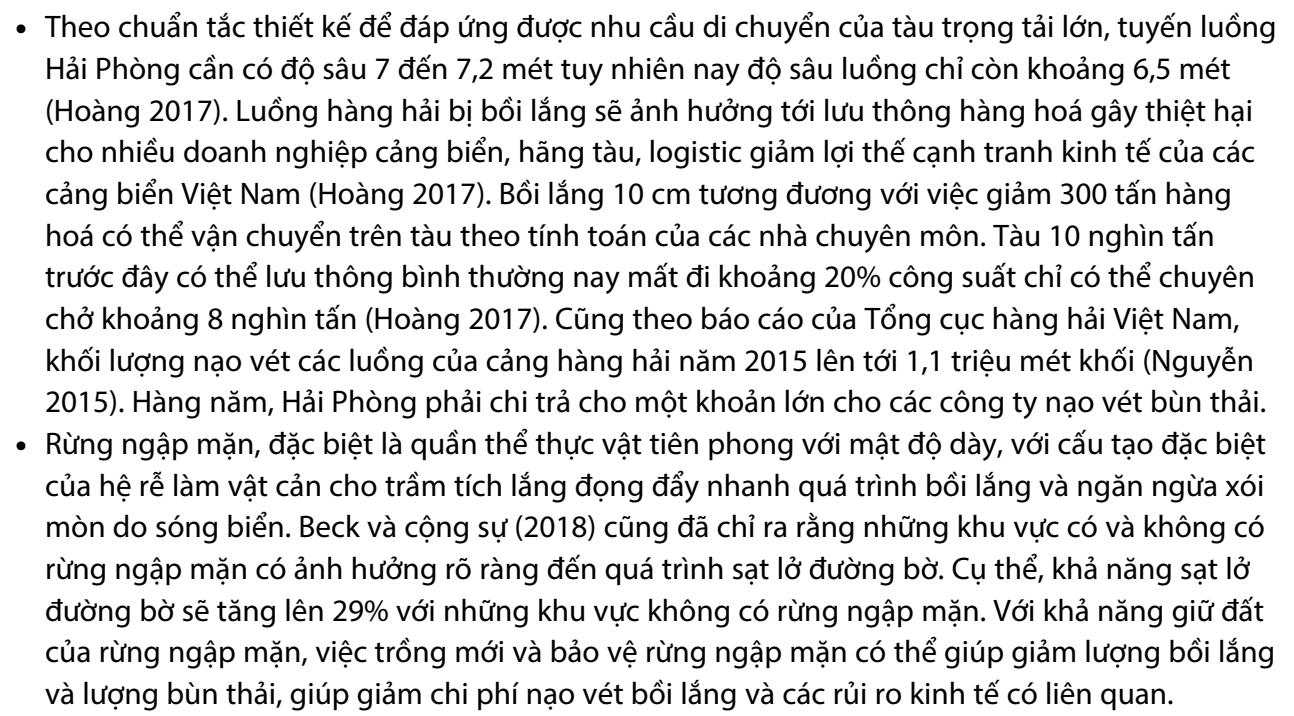 \\
\hline
\end{tabular}

3. Chống xói lở bờ biển
- Xói lở đường bờ chủ yếu chịu tác động lớn của hình dáng đường bờ, hướng sóng, năng lượng sóng, vận tốc dòng chảy và biên độ triều. Khi xảy ra xói lở bờ biển, rất nhiều ngành nghề kinh tế (ví dụ: cảng cá, cảng biển, cảng quốc phòng) cũng như các bên có liên quan bị ảnh hưởng.Ví dụ, khi sạt lở bờ biển, các khu khách sạn resort hoặc các cảng sẽ bị ảnh hưởng do sụt lún công trình cơ sở hạ tầng và sẽ phải bỏ ra nhiều chi phí khắc phục, sửa chữa. Việc sụt lún cũng gây ra mất đất của hộ gia đình và công ty đang kinh doanh trong lĩnh vực nông, lâm, thuỷ sản. Mặt khác, rất nhiều đối tượng và ngành nghề cũng đang gây xói lở bờ biển bởi các hoạt động kinh doanh của mình (ví dụ: khai thác cát; xây dựng cảng...) làm giảm diện tích rừng ngập mặn và làm tăng tốc độ xói lở đường bờ vì vùng ven bờ bị mất vành đai thực bì bảo vệ.

- Mức độ góp phần làm giảm xói lở của rừng ngập mặn có xu thế khá cục bộ. Ở một số nơi lực xói lở yếu, sự hiện diện của rừng ngập mặn ít nhiều đủ sức chống xói lở; còn ở nơi lực xói lở mạnh hơn, rừng ngập mặn có thể giúp làm giảm tốc độ xói lở một cách đáng kể. Nhưng ở những nơi năng lượng sóng ven bờ quá lớn, tác dụng của rừng ngập mặn là rất thấp hoặc không còn tác dụng phòng chống xói lở ven bờ.

4. Chắn sóng

RNM có tác dụng làm giảm độ cao và năng lượng truyền đi của sóng. Khi triều cường, độ cao sóng biển giảm mạnh khi đi qua dải RNM, với mức biến đổi từ $75 \%$ đến $85 \%$, từ $1,3 \mathrm{~m}$ xuống 0,2m - 0,3m (Phan, 2011). Khi cơn bão số 7 (29/9/2005) vào bờ biển huyện Thái Thuy, tỉnh Thái Bình, hơn $5 \mathrm{~km}$ bờ đê quốc gia ở xã Thái Đô chưa được bê tông hoá không bị sứt mẻ, trong khi đó $650 \mathrm{~m}$ đê còn lại của xã đó ở xóm Tân Bồi chưa có RNM bảo vệ thì bị xói lở nghiêm trọng (Lê, Phan và Trương 2008). Rừng ngập mặn nên được coi là một hạng mục thành phần của các công trình đê biển để từ đó có được đầu tư thoả đáng để chăm sóc và bảo vệ. 
Bảng 1. Tiếp trang trước

\begin{tabular}{|c|c|}
\hline Dịch vụ & Tóm tắt luận giải vai trò của rừng ngập mặn \\
\hline $\begin{array}{l}\text { 5. Cung ứng nước } \\
\text { sạch, lọc kim loại } \\
\text { nặng và chất ô } \\
\text { nhiễm; }\end{array}$ & $\begin{array}{l}\text { Là vùng chuyển tiếp giữa biển và đất liền, đất ngập mặn tiếp nhận các chất bẩn từ vòng tuần } \\
\text { hoàn của thủy triều, sông và dòng chảy bề mặt của đất (Tam và Wong 1993, Tam và Wong 1996). } \\
\text { Theo ước tính, có tữ } 75 \text { \% đến } 90 \% \text { tổng dòng vật chất liên lục bị tích luỹ ở môi trường bờ biển } \\
\text { (Berner và Raiswell 1983). Rừng ngập mặn đã được ghi nhận là nơi chứa các chất gây nhiễm bẩn, } \\
\text { bao gồm nitrogen (Tam và cộng sự 1995), các chất vô cơ và hữu cơ gây ô nhiễm môi trường } \\
\text { (Maskaoui và cộng sự 2002). Do rừng ngập mặn có khả năng bẫy các chất thải lơ lửng trong cột } \\
\text { nước hiệu quả (Furukawa, Wolanski và cộng sự 1997) và cóa ái lực cao của chất hữu cớ (OM) với } \\
\text { kim loại, nên các trầm tích rừng ngập mặn có một dung lượng lớn để tích lũy các chất gây ô } \\
\text { nhiễm này (Harbison 1986, Tam và Wong 2000, Marchand và cộng sự 2011). Do đó, các khu vực } \\
\text { ven biển có thể hoạt động như các bộ lọc, giữ lại các vật chất được thải ra bởi các con sông, bầu } \\
\text { khí quyển, và đại dương trong thời gian tương đối dài (Berner 1984, Kjerfve và Magill 1989) }\end{array}$ \\
\hline 6. Cung ứng bãi đẻ & $\begin{array}{l}\text { Việc mất rừng ngập mặn làm giảm đáng kể số lượng sinh vật phù du và sinh vật tầng đáy mà là } \\
\text { thức ăn cho các loài thuỷ sản, dẫn đến tình trạng giảm sút năng suất tôm nuôi theo hình thức } \\
\text { quảng canh: năm } 1980 \text { là } 200-250 \mathrm{~kg} / \mathrm{ha} / \mathrm{vu} \text {, đến } 2001 \text { chỉ còn } 70-80 \mathrm{~kg} / \mathrm{ha} / \mathrm{vụ} \mathrm{(MARD} \mathrm{2010).} \mathrm{Theo} \\
\text { ước tính, cứ } 1 \text { ha RNM trước đây có thể khai thác được từ } 700-1000 \mathrm{~kg} \text { thuỷ sản, nhưng hiện nay } \\
\text { chỉ thu được } 1 / 20 \text { so với trước đây (MARD 2010). }\end{array}$ \\
\hline $\begin{array}{l}\text { 7. Dịch vụ du lịch/vẻ } \\
\text { đẹp cảnh quan }\end{array}$ & $\begin{array}{l}\text { Rừng ngập mặn cung cấp cảnh quan từ đó các công ty du lịch có thể kinh doanh các loại hình } \\
\text { dịch vụ du lịch tại Hải Phòng }\end{array}$ \\
\hline $\begin{array}{l}\text { 8. Cung cấp nguyên } \\
\text { liệu thực phẩm }\end{array}$ & $\begin{array}{l}\text { Tại Hải Phòng, một số doanh nghiệp địa phương hiện đang phát triển một số sản phẩm rượu } \\
\text { vang, nước giải khát và mật ong với nguồn nguyên liệu thu được trực tiếp từ rừng ngập mặn. }\end{array}$ \\
\hline
\end{tabular}

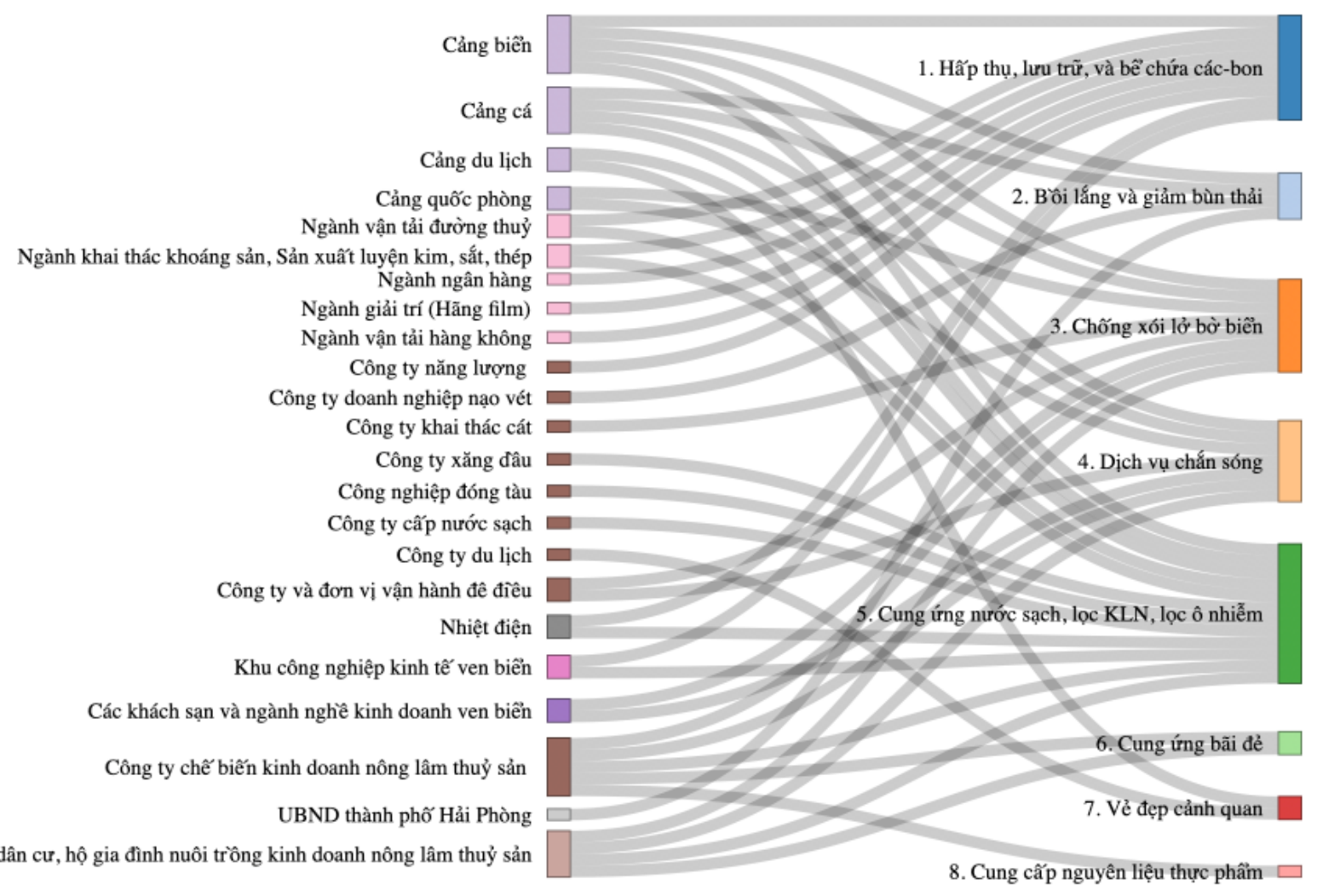

Hình 4. Các nhóm người mua tiềm năng các dịch vụ rừng ngập mặn (Nguồn: Nhóm tác giả 2020) 


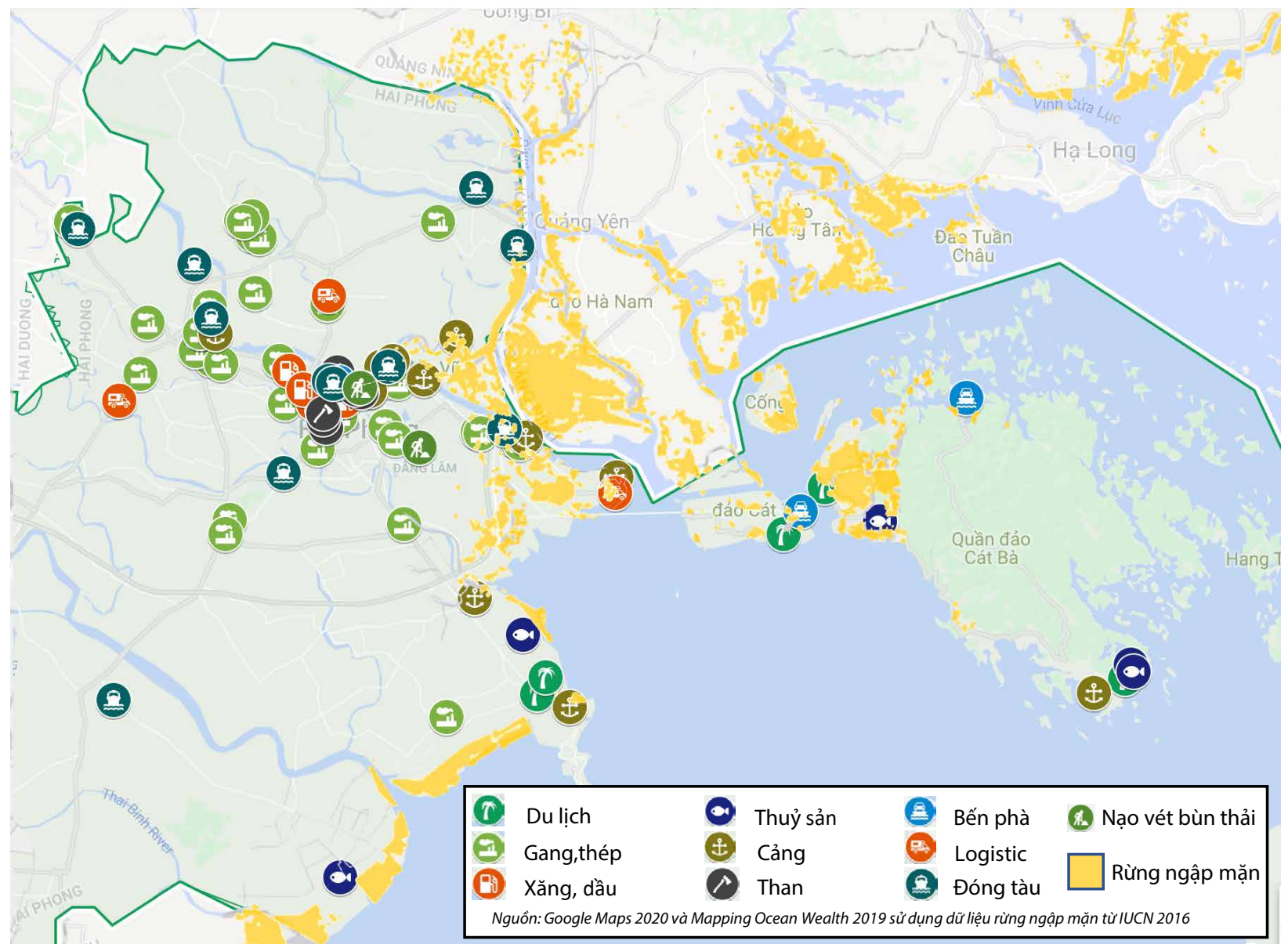

Hình 5. Bản đồ phân bố một số ngành nghề tại Hải Phòng (Nguồn: Nhóm tác giả tổng hợp từ Google Maps và Mapping Ocean Wealth 2019 sử dụng dữ liệu rừng ngập mặn từ IUCN 2016)

Lưu ý: sự phân bố các ngành nghề được thể hiện thông qua các công ty có đặt dữ liệu vị trí trên Google Maps

Có 20 nhóm người mua dịch vụ môi trường rừng ngập mặn tiềm năng trên địa bàn Hải Phòng bao gồm: Công ty doanh nghiệp nạo vét, công ty năng lượng, ngành giải trí, ngành ngân hàng, ngành vận tải hàng không, cảng cá, cảng biển, khu kinh tế ven biển, công ty khai thác cát, ngành khai thác khoáng sản và luyện kim, ngành vận tải, ngành nhiệt điện, các nhóm quản lí đê điều, công ty du lịch, cộng đồng dân cư, công nghiệp đóng tàu, công ty sản xuất mặt hàng nông, lâm, thủy hải sản, công ty xăng dầu và công ty nước sạch. Trong khi một số nhóm người mua đã thể hiện cam kết cao cho việc tiến hành chi trả (vd: Ngân hàng, Năng lượng, Công ty sản xuất các sản phẩm nông, lâm thủy hải sản), nhưng cần có thêm nhiều nghiên cứu trong tương lai để tìm hiểu mức sẵn lòng chi trả của các bên còn lại trong việc tham gia PFES.

\section{Thảo luận và Đề xuất}

Kết quả nghiên cứu tiền khả thi đã cho thấy tiềm năng và tính khả thi của việc xây dựng cơ chế PFES cho rừng ngập mặn tại Hải Phòng bởi rừng ngập mặn có thể đem lại dịch vụ môi trường rừng cho nhiều bên có liên quan. Hải Phòng là thành phố đặt ra những cam kết chính trị về việc thực hiện phát triển kinh tế đi đôi với bảo vệ môi trường nên đã có sẵn nền tảng cam kết chính trị cao. Tuy nhiên, kết quả nghiên cứu tiền khả thi của chúng tôi cho thấy cần có thêm các nghiên cứu đầy đủ, chính xác và khoa học cho từng loại dịch vụ liên quan đến minh chứng khoa học của lợi ích về dịch vụ môi trường mà rừng ngập mặn đem lại, mức sẵn lòng chi trả của những người mua tiềm năng, nghiên cứu cơ chế thu và chi cùng cơ chế giám sát và đánh giá để theo 
dõi cũng như đánh giá tác động của từng cơ chế PFES rừng ngập mặn với từng loại dịch vụ khác nhau.

Với tiềm lực ngân sách và thời gian hạn chế của dự án, trong 8 dịch vụ môi trường rừng tiềm năng, CIFOR chọn 2 dịch vụ môi trường là dịch vụ nước sạch - lọc kim loại nặng và hấp thụ các-bon để tiến hành các nghiên cứu sâu hơn bởi 4 lí do sau: (i) Các phân tích phía trên cho thấy hai dịch vụ này có số lượng người mua tiềm năng lớn nhất; (ii) Việc thu tiền PFES cho rừng ngập mặn đối với các bên sử dụng dịch vụ như hệ thống cảng hoàn toàn có thể dựa trên vào hệ thống thu phí tại cảng nên tính khả thi cao hơn so với các dịch vụ khác; (iii) cơ chế chi trả các-bon đang được thí điểm tại Việt Nam dưới Nghị định 156 và việc mở rộng cơ chế này đối với rừng ngập mặn sẽ có những đóng góp tích cực cho việc hoàn thiện chính sách PFES cho các-bon. Hơn nữa, thị trường các-bon và mối quan tâm với tín chỉ các-bon đã được hình thành từ lâu nên người mua tiềm năng đã có nền tảng kiến thức và quan tâm rõ ràng; và (iv) hai dịch vụ môi trường này không chỉ áp dụng đối với rừng ngập mặn mà còn có thể áp dụng được với cả rừng trên cạn nên sẽ có thể tạo hiệu ứng nhân rộng tích cực cho PFES.

Để xây dựng cơ chế chi trả cho các dịch vụ môi trường rừng ngặp mặn tiềm năng kể trên, cần phải trả lời cho 4 câu hỏi chính: (1) Chi trả cho dịch vụ nào? (2) Ai là người chi trả? (3) Mức chi trả là bao nhiêu?; và (4) Cơ chế thu chi như thế nào? Việc trả lời 4 câu hỏi trên đòi hỏi phải có các nghiên cứu bài bản trong một thời gian đủ dài, đặc biệt minh chứng cho mối quan hệ giữa các bên đối với dịch vụ môi trường rừng sử dụng. Dựa trên kết quả nghiên cứu tiền khả thi năm 2018- 2019, tóm lược chính sách này trả lời 2 câu hỏi đầu. 2 câu hỏi cuối sẽ được trả lời tại một tóm lược chính sách khác sau khi nghiên cứu hoàn thành vào cuối năm 2020.

Cho tới nay, việc tìm kiếm và đảm bảo ngân sách cho bảo vệ rừng ngập mặn luôn gặp khó khăn. Ngay cả khi xác định được dịch vụ tiềm năng, việc chứng minh và vận hành cơ chế đó không hề dễ dàng. Tuy nhiên, việc Hải Phòng đã có sẵn Quỹ Phát triển bền vững khu dự trữ sinh quyển Cát Bà với một cơ chế huy động đóng góp tự nguyện của các bên liên quan. Sử dụng nguồn thu này có hiệu quả có thể là mô hình mà PFES nên xem xét để áp dụng. Việc có nhiều doanh nghiệp trong địa bàn tự nguyện đóng góp tiền bảo vệ môi trường, trong đó có dành ra ngân sách để trồng mới rừng ngập mặn, mở ra một cách tiếp cận mới trong việc thúc đẩy cơ chế tự nguyện của PFES tại Việt nam. Cần có nhiều nghiên cứu hơn nữa về vấn đề này.

\section{Lời cảm ơn}

Chúng tôi xin trân trọng cảm ơn hỗ trợ tài chính từ các nhà tài trợ bao gồm Cơ quan Hợp tác Phát triển Na Uy (NORAD), Cơ quan phát triển Mỹ (USAID) và Chương trình nghiên cứu CGIAR về rừng, cây và nông lâm kết hợp (CRP-FTA), đã hỗ trợnghiên cứu này.

\section{Tài liệu tham khảo}

Alongi DM. 2012. Carbon sequestration in mangrove forests. Carbon management 3(3):313-22.

Beck MW, Losada IJ, Menéndez P, Reguero BG, Díaz-Simal $P$ and Fernández F. 2018. The global flood protection savings provided by coral reefs. Nature communications 9(1):1-9.

Berner RA and Raiswell R. 1983. Burial of organic các-bon and pyrite sulfur in sediments over Phanerozoi time: a new theory. Geochimica et Cosmochimica Acta 47:855-62.

Berner RA. 1984. Sedimentary pyrite formation: An update. Geochimica et Cosmochimica Acta 48:605-15.

Donato DC, Kauffman JB, Murdiyarso D, Kurnianto S, Stidham $M$ and Kanninen M. 2011. Mangroves among the most carbon-rich forests in the tropics. Nature geoscience, 4(5), pp.293-297.

Furukawa K, Wolanski E and Mueller H. 1997. Currents and Sediment Transport in Mangrove Forests. Estuarine, Coastal and Shelf Science, 44(3), pp.301-310.

Harbison P. 1986. Mangrove muds-A sink and a source for trace metals. Mar Pollut Bull 17:246-50.

Hoàng T. 2017. Thiệt hại do chậm nạo vét luồng hàng hải Hải Phòng. Báo Nhân dân. Truy cập ngày 24/04/2020: https://www.nhandan.com.vn/kinhte/item/35029902thiet-hai-do-cham-nao-vet-luong-hang-hai-hai-phong. html

Kjerfve B and Magill KE. 1989. Geographic and hydrodynamic charactersistics of shallow coastal lagoons. Marine Geology 88:187-99.

Lê XT, Phan NH, Trương QH. 2008. Những vấn đề về môi trường ven biển và phục hồi rừng ngập mặn tại Việt Nam. Accessed on 24/02/2020: http://thuvien.ued.udn.vn:8080/ dspace/bitstream/TVDHSPDN_123456789/44996/2/ LE\%20XUAN\%20TUAN.pdf

Marchand C, Allenbach M and Lallier-Vergès E. 2011. Relationships between heavy metals distribution and organic matter cycling in mangrove sediments (Conception Bay, New Caledonia). Geoderma, 160(3-4), pp.444-456. 
MARD. 2010. Biến đổi khí hậu và những ảnh hưởng lên nghề cá tại các khu vực rừng ngập mặn ven biển. Truy cập ngày 24/02/2020: https://www.mard.gov.vn/Pages/ bien-doi-khi-hau-va-nhung-anh-huong-len-nghe-ca-taicac-khu-vuc-rung-ngap-man-ven-bien-4378.aspx

Maskaoui K, Zhou JL, Hong HS and Zhang ZL. 2002.

Contamination by polycyclic aromatic hydrocarbons in the Jiulong River estuary and Western Xiamen Sea, China. Environmental pollution, 118(1), pp.109-122.

Nguyễn TMH. 2015. Nghiên cứu cơ sở pháp lý và thực tiễn về hoạt động đổ thải chất nạo vét luồng cảng tại thành phố Hải Phòng [Luận văn Thạc sỹ]. Hà Nội: Đại học quốc gia Hà Nội

Phạm TT, Vũ TP, Phạm ĐC, Đào LHT, Nguyen VT, Hoang NVH, Hoang TL, Đào TLC và Nguyen DT. 2019. Cơ hội và thách thức đối với quản lý rừng ngập mặn tại Việt Nam: Bài học từ các tỉnh Thanh Hóa, Thái Bình và Quảng Ninh. Báo cáo chuyên đề 198. Bogor, Indonesia: CIFOR.

Phan L. 2011. Tác dụng của rừng ngập mặn trong bối cảnh biến đổi khí hậu. Truy cập ngày 24/02/2020: https://stnmt. binhdinh.gov.vn/mnewsdetail.php?newsid=311\&id=42\&n ewsid $=311$ \&id $=42$

Sasmito SD, Taillardat P, Clendenning JN, Cameron C, Friess DA, Murdiyarso D and Hutley LB. 2019. Effect of land-use and land-cover change on mangrove blue carbon: $A$ systematic review. Global change biology 25(12):4291-302.

Tam NF, Li SH, Lan CY, Chen GZ, Li MS and Wong YS. 1995. Nutrients and heavy metal contamination of plants and sediments in Futian mangrove forest. Hydrobiologia, 295(1-3), pp.149-158.

Tam NFY and Wong YS. 1993. Retention of nutrients and heavy metals in mangrove sediment receiving wastewater of different strengths. Environmental Technology 14(8):719-29.

Tam NFY and Wong YS. 1996. Retention and distribution of heavy metals in mangrove soils receiving wastewater. Environmental Pollution 94(3):283-91.

Tam NFY and Wong YS. 2000. Spatial variation of heavy metals in surface sediments of Hong Kong mangrove swamps. Environmental Pollution 110:195-205.
Chương trình nghiên cứu của CGIAR về Rừng, Cây gỗ và Nông lâm kết hợp (FTA) là chương trình phát triển nghiên cứu lớn nhất thế giới nhằm nâng cao vai trò của rừng, cây gỗ và nông lâm kết hợp với mục tiêu phát triển bền vững và đảm bảo lương thực để ứng phó với biến đổi khí hậu. CIFOR chủ trì các nghiên cứu FTA trong mối quan hệ đối tác chiến lược với Bioversity International, CATIE, CIRAD, INBAR, ICRAF và TBI.

Nghiên cứu này được hỗ trợ bởi Quỹ đối tác CGIAR: cigar.org/funders/

\section{Norad (2) USAID} nghiên cứu sáng tạo, nâng cao năng lực của các bên đối tác, tích cực tham gia đối thoại với các bên liên quan để hỗ trợ định hình chính sách và thực tiễn tác động tới rừng và con người. CIFOR là tổ chức nghiên cứu thuộc liên minh CGIAR và chủ trì các chương trình nghiên cứu của CGIAR về Rừng, Cây gỗ và Nông lâm kết hợp (FTA). Trụ sở chính của CIFOR đặt tại Bogor, Indonesia và các văn phòng của CIFOR có mặt tại Nairobi, Kenya; Yaounde, Cameroon; Lima, Peru và Bonn, Germany. 